九州大学学術情報リポジトリ

Kyushu University Institutional Repository

\title{
Detection of Penicillin-Binding Proteins in Bacillus Cereus by Using Biotinylated $\beta-$ Lactams
}

Miyamoto, Takahisa

Laboratory of Food Hygienic Chemistry, Division of Bioresource and Bioenvironmental Sciences, Graduate School, Kyushu University

Sukimoto, Kouj i

Laboratory of Food Hygienic Chemistry, Division of Bioresource and Bioenvironmental Sciences, Graduate School, Kyushu University

Sayed, Md Abu

Laboratory of Food Hygienic Chemistry, Division of Bioresource and Bioenvironmental Sciences, Graduate School, Kyushu University

Kim, Sam-In

Laboratory of Food Hygienic Chemistry, Division of Bioresource and Bioenvironmental Sciences, Graduate School, Kyushu University

他

https://doi.org/10.5109/24332

出版情報：九州大学大学院農学研究院紀要. 44 (3/4)，pp. 299-307，2000-02. Kyushu University バージョン：

権利関係 : 


\title{
Detection of Penicillin-Binding Proteins in Bacillus Cereus by Using Biotinylated $\beta$-Lactams
}

\author{
Takahisa Miyamoto, Kouji Sukimoto, Md Abu Sayed, Sam-In Kim, \\ Ken-ichi Honjoh and Shoji Hatano*
}

\author{
Laboratory of Food Hygienic Chemistry, Division of Bioresource and \\ Bioenvironmental Sciences, Graduate School, Kyusłı University; \\ Fukuoka 812-8581, Japan \\ (Received September 17, 1999 and accepted Nonember 5, 1999)
}

\begin{abstract}
A new method for detcetion of ponicilin binding proteins from bacterial membranes has becn developed in this study. The method, that employed biotin ampicillin conjugate ( $13 \mathrm{~B}_{0}-\mathrm{PCA}$ ), is very rapid and can be a significant alternative of hazardous and time consumimng conventional radiometric method for detection of PBPs in ccll membranes. PBPs from $B$. cerens were exartined by this techuique. In vegetative and sporulating cells, 8 major PBI's were drtected. Comparing with standard nuarker proteins, these Pl3Ps were estimated for their molecular weight as $106,83,75,72,63,46,40$, and $32 \mathrm{kDa}$. Affinity of cephalcxin, cefoxitin, and cefotaxime to PIP's was measured indirectly by competition for subsequent birding of Bio- $\mathrm{PCA}^{\mathrm{C}}$. PBPs 2, 3, 4, and 7 were decreascd or disappeared in the electrophoregram by prebinding with these $\beta$-lactams. Two PBPs, PBP 3 and PBP 4 , which were predominant in vegetative and sporulating cells, respectively, showed strong affinily for cephalexirl.
\end{abstract}

\section{INTRODUCTION}

The penicillin-binding proteins (PBPs) are a farnily of membrane-bound enzymes that are active in the metabolism of prokaryotic cell walls. They are evolutionarily related to some of the soluble $\beta$-lactamases and D, D-peptidases secreted by bacteria and also have some structural features in common with a penicillin-binding transmembrane protein involved in signal transduction (Joris et al., 1990). Peptidoglycan is the major structural element of cell wall in eubacteria. Peptidoglycan synthesis is necessary not. only for the maintenance of cell morphology but also for survival. PBPs function in peptidoglycan synthesis with their dual enzymatic activities, a transglycosylase activity that polymerizes the glycan strands and a transpeptidase activity that cross-links them via thcir peptide side chains. All bacteria have multiple PBPs. Some PBPs seem dispensable whereas others are essential for peptidoglycan syntheses. Each bacterial species has its own assortment of PBPs.

In Escherichia coli, there are eight well-characterized PBPs. These PBPs are generally divided into two classes, the higher molecular mass PBPs (PBP 1a/1b, PBP 2, and PBP 3) and the lower molecular mass PBPs (PBP 4, PBP 5, PBP 6, and PBP 7), numerically numbered in the order of their decreasing mobility in sodium dodecyl sulfate (SDS)-polyacrylamide gels (Waxman and Strominger, 1983). The higher molecular mass

\footnotetext{
* present. address: Nishikyushu Universily, Saga 842-8585, Japan
} 
PBPs are bifunctional enzymes. They are generally 1), D-transpeptidases, but in addition they have transglycosylase activity. These enzyme activities are essential for murein metabolism during bacterial growth and division, and they are the targets of the $\beta$-lactan antibiotics (Suzuki et al., 1978). The lower molecular mass PBPs are generally monofunctional D, D-carboxypeptidases, and they do not seem to be essential for the growth and division of $E$. coli.

In Bacillus subtilis, seven high molecular mass PBPs, and four low-molecular mass PBPs have been identified (Blumberg and Strominger, 1972; Buchanan and Gustafson, 1992; Daniel et al., 1994; Kleppe and Strominger, 1979; Sowell and Buchanan, 1983; Todd et al. 1983; Wu and Piggot, 1992). While most of these PBPs are present in vegetatively growing cells, some are specific to sporulation. Synthesis of cell-wall component peptidoglycan is important for two major morphological events of sporulation. Soon after the induction of sporulation of $B$. subtilis, the presporc and mother cell are separated by an asymmetric septum, which contains a thin layer of peptidoglycan. Around two hours after induction, a modified form of peptidoglycan is laid down between the membranes separating the prespore and mother cell to form a layer known as cortex.

Bacillus cereus is one of the food poisoning bacteria and produces heat resistant enterotoxin and spores. The presence of its spore in lood is one of the biggest problems in food industry, since the spore is resistant to heating, ultra violet light and drugs. We have shown that cephalexin effectively inhibited sporulation of $B$. cereus. By using $\left[{ }^{3} \mathrm{H}\right]$ benzylpenicillin, eight PBPs were detected from the cells of $B$. cereus. We have found two PBPs in $B$. cereus ts 4 , with molecular masses of $75 \mathrm{kDa}$ and $72 \mathrm{kDa}$, have high affinity for cephalexin (Miyamoto et al., 1997).

PBPs are conventionally identified by [ ${ }^{[25}[]$ ampicillin or ["H]benzylpenicillin. However, radiometric method is hazardous and rather time consuming. Recently, two promising methods for the non-radiometric identification of PBPs from bacterial membranes have been reported, one employed digoxigenin labeled ampicillin, whereas the other one exploited fluorescein-labeled penicillins to detect PBPs upon illumination with UV light or a laser beam (Weigel et al., 1994; Galleni et al., 1993).

In this paper, we have tried to develop a new and simple method using biotinylated $\beta$ -lactams for the detection of bacterial PBPs and investigated the PBP profile of vegetative and sporulating cells of $B$. cereus.

\section{MATERIALS AND METHODS}

\section{Bacterial strains and culture conditions}

Escherichia coli IFO 3301 and Bacillus cereus JCM 2152 were obtained from Institute of Fermentation, Osaka and Japan Collection of Microorganisms, Wako, Saitama, respectively. Bacillus cereus ts 4 was a tempcrature sensitive mutant of $B$. cereus JCM 2152 isolated in our laboratory. $E$. coli was cultivated in LB broth at $30^{\circ} \mathrm{C}$ with shaking. B. cereus was cultivated as described previously (Miyamoto et al., 1997).

\section{Preparation of bacterial membrane}

Membrane fractions were prepared according to the method of Buchanan (1979) with little modifications. Vegetative and sporulating cells were harvested by centrifugation at 
$1,400 \times g$ for $5 \mathrm{~min}$ at $4^{\circ} \mathrm{C}$, washed once with a membrane preparation buffer (MP buffer; $50 \mathrm{mM}$ Tris- $\mathrm{HCl}$ buffer, $\mathrm{pH} 7.6$, containing $1 \mathrm{mM} \mathrm{MgCl}_{2}, 1 \mathrm{mM}$ phenylmethylsulfonylfluoride) at $4^{\circ} \mathrm{C}$ and all further steps were carried out at $4^{\circ} \mathrm{C}$. The cells were disrupted by ten 30-sec pulses for vegetative cells and twenty 30-sec pulses for sporulating cells with a Branson Sonifier model 185 at $60 \mathrm{~W}$. Unbroken cells were removed by centrifugation at $8,500 \times \mathrm{g}$ for $15 \mathrm{~min}$. Membranes were pelleted by ultracentrifugation at $100,000 \times \mathrm{g}$ for $1 \mathrm{~h}$ and washed once with MP buffer. Membrane fractions were then dissolved in a small volume of MP buffer. Proteins were measured by the dye binding method of Bradford (1976).

\section{Biotinylation of $\beta$-lactams}

Two milligrams of $\beta$-lactams (ampicillin, cephalexin, cefoxitin, and cefotaxime) in $1 \mathrm{ml}$ of phosphate-buffered saline, $\mathrm{pH} 8.5$ (PBS) was incubated for $2 \mathrm{~h}$ at room temperature with $1 \mathrm{mg}$ of D-biotinylated- $\varepsilon$-aminocaproic acid-N-hydroxysuccinimide ester (Biotin-X-NIIS ester, Boehringer Mannheim GmbH, Mannheim, Germany) dissolved in $100 \mu \mathrm{l}$ of dimethyl sulfoxide. Unconjugated Biotin-X-NHS ester was trapped with glycine in a final concentration of $5 \mathrm{mM}$. Biotinylated antibiotic was purified by gel filtration on a Bio-Gel P2 column (Bio-Rad, CA, USA) equilibrated with PBS ( $\mathrm{pH}$ 8.5). The concentrations of biotinylated $\beta$-lactams were calculated to be $1.5 \mathrm{mg} / \mathrm{ml}$. The biotinylated ampicillin, cephalexin, cefoxitin, and cefotaxime were abbreviated as Bio-PCA, -CEX, -CFT, and-CTX, respectively. Structures of $\beta$-lactams and biotinylated ones used are shown in Fig. 1.

\section{SDS-polyacrylamide gel electrophoresis}

SDS-polyacrylamide gel clectrophoresis (SDS-PAGE) was performed in a $10 \%$ acrylamide gel according to the method of Laemmli (1970). Gels were stained with $0.1 \%$ coomassie brilliant blue R-250 dissolved in $20 \%$ methanol solution containing $10 \%$ acetic acid and proteins were visualized by destaining the gel with $50 \%$ methanol solution containing $5 \%$ acetic acid.

\section{Detection of PBPs with biotinylated $\beta$-lactams}

Labeling of 'BPs with biotinylated ampicillin (Bio-PCA) and other biotinylated $\beta$ -lactams was principally same as that with ["H|benzylpenicillin (Miyamoto et al., 1997). Two microliter of biotinylated $\beta$-lactam $(0.03,0.3$, or $3 \mu \mathrm{g}$ as unlabeled $\beta$-lactam) was added to $500 \mu \mathrm{g}$ of membrane protein in a final volume of $30 \mu \mathrm{l}$ of $100 \mathrm{mM}$ Tris-HCl buffer $(\mathrm{pH} 7.6)$ and incubated for $30 \mathrm{~min}$ at $25^{\circ} \mathrm{C}$. The labeled proteins were solubilized and separated in a $10 \%$ acrylamide gel as described above. The proteins were electroblotted onto a nitrocellulose membrane. The membrane was washed with water for $3 \mathrm{~min}$ and blocked in Tris-buffered saline (TBS: $100 \mathrm{mM}$ Tris-HCl buffer, $\mathrm{pH} 7.5$, containing $0.9 \%$ $\mathrm{NaCl}$ ) containing $0.1 \%$ Tween 20 for $15 \mathrm{~min}$ and was treated for $30 \mathrm{~min}$ with streptavidin-horse radish pcroxidase conjugate (Amersham Inter. plc. Amersham, LK) diluted 1,000-fold with TBS containing $0.01 \%$ Tween 20 (TTBS). Excess peroxidase was removed by washing the membrane 4 times with TTBS and the washed membrane was equilibrated in $50 \mathrm{mM}$ Tris- $\mathrm{HCl}$ buffer $(\mathrm{pH} \mathrm{7.5)}$ for $10 \mathrm{~min}$. For visualization of PBPs, the membrane was treated for $1 \mathrm{~min}$ in visualization solution ( $50 \mathrm{mM}$ Tris-HCl buffer, $\mathrm{pH} 7.5$, 


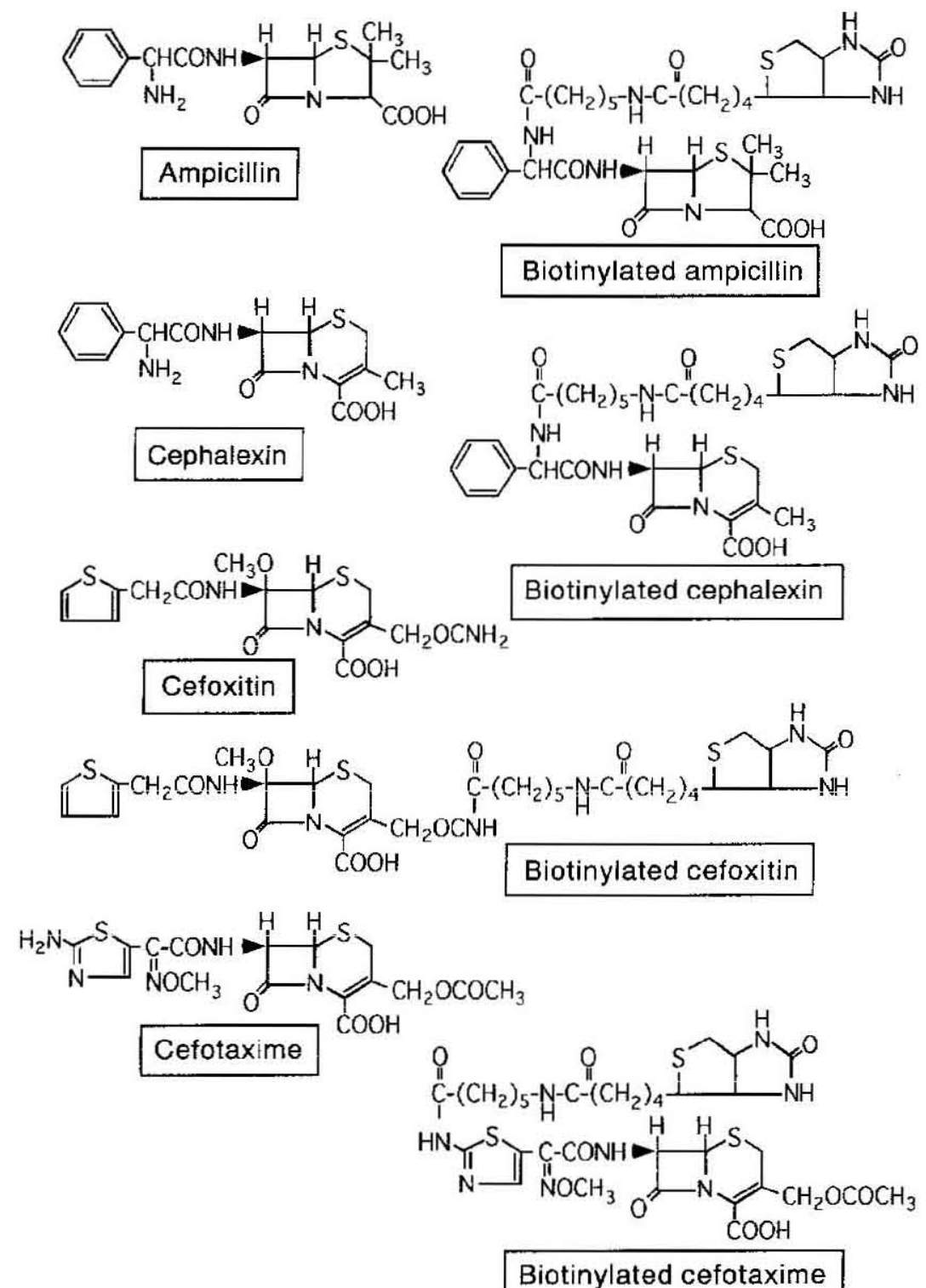

Fig. 1. Structures of $\beta$-lactams labeled with biotin.

containing $0.4 \mathrm{mg} / \mathrm{ml}$ luminol, $0.1 \mathrm{mg} / \mathrm{ml} p$-iodophenol and $0.02 \%$ hydrogen peroxide) and then immediately placed in a plastic bag and exposed to a Fuji RX X-ray film for a minimal 20 min to overnight.

Competition assay was performed for measurement of the binding of cephalexin, 
Cefoxitin and cefotaxime to PBPs, the menorane protein was incubated with undabeded $\beta$ -lactams at 10 and $100 \mu \mathrm{g} / \mathrm{ml}$ for $10 \mathrm{~min}$ at $25^{\circ} \mathrm{C}$ before incubation with Bio-PCA at $100 \mu \mathrm{g} / \mathrm{ml}$.

\section{RESULTS}

\section{Detection of PBPs of $E$. coli by using biotinylated ampicillin}

The PBP pattern of E. coli IFO 3301 (K12 strain) detected by Bio-PCA is shown in Fig. 2. Seven PBPs were detected from the membrane preparation from $E$. coli. Their molecular masses were calculated to be $90,89,66,60,49,42$, and $40 \mathrm{kDa}$. To examine the concentration dependency of Bio-PCA on binding to E. coli PBPs, membrane proteins were incubated with graded concentrations of Bio-PCA. PBPs 3 and 5/6 were labeled at the lowest concentration of Bio-PCA tested, while the full complement of PBPs was detected at $10 \mu \mathrm{g} / \mathrm{ml}$.

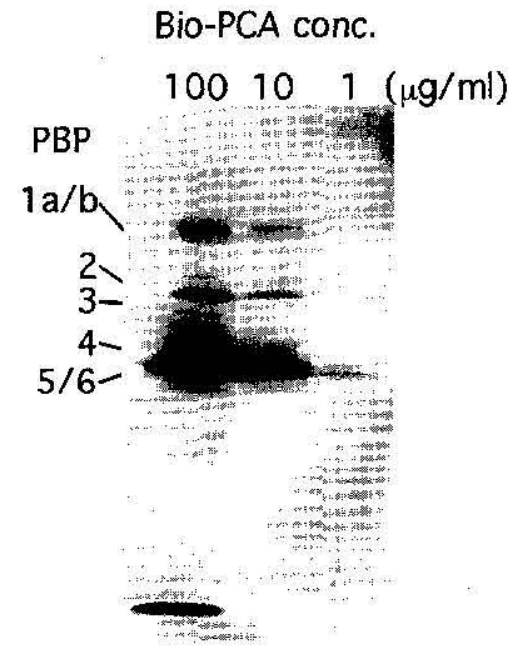

Fig. 2. Binding of $E$. coli, PBPs with biotinylated ampicillin. $E$. coli membrane proteins were treated with biotinylated ampicillin (Bio-PCA) at a concentration of 1,10 and $100 \mu \mathrm{g} / \mathrm{mnl}$.

\section{Detection of PBPs of $B$. cereus by using biotinylated $\beta$-lactams}

By using Bio-PCA, PBPs were detected from the cells of $B$. cereus ts -4 in mid-exponential growth and from sporulating cells after $3 \mathrm{~h}$ of induction. Fig. 3 shows the SDS-PAGE profiles of PBPs of vegetative and sporulating cells of $B$. cereus ts 4 by using biotinylated $\beta$-lactams. In vegetative and sporulating cells, 8 major PBPs were detected. In the initial stage of sporulation, PBPs $3,4,6,7$, and 8 were detected in the 


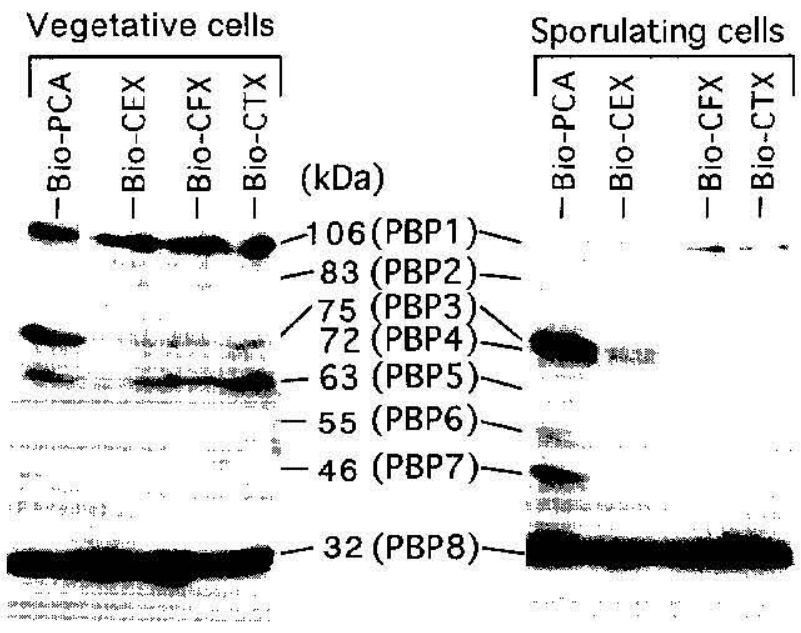

Fig. 3. SDS-PAGE profiles of PBPs of 13 . cereus ts-4 labeled with biotinylated $\beta$-lactams. Membrane proteirs of $B$. cereus ts -4 were prepared from vegetative and sporulating cells by the method described in the text. The proteins were incubated with $100 \mu \mathrm{g} / \mathrm{ml}$ biotinylated ampicillin (Bio-PCA), cephalexin (Bio-CEX), cefoxitin (Bio-CFX), and cefotaxime (Bio-CTX).

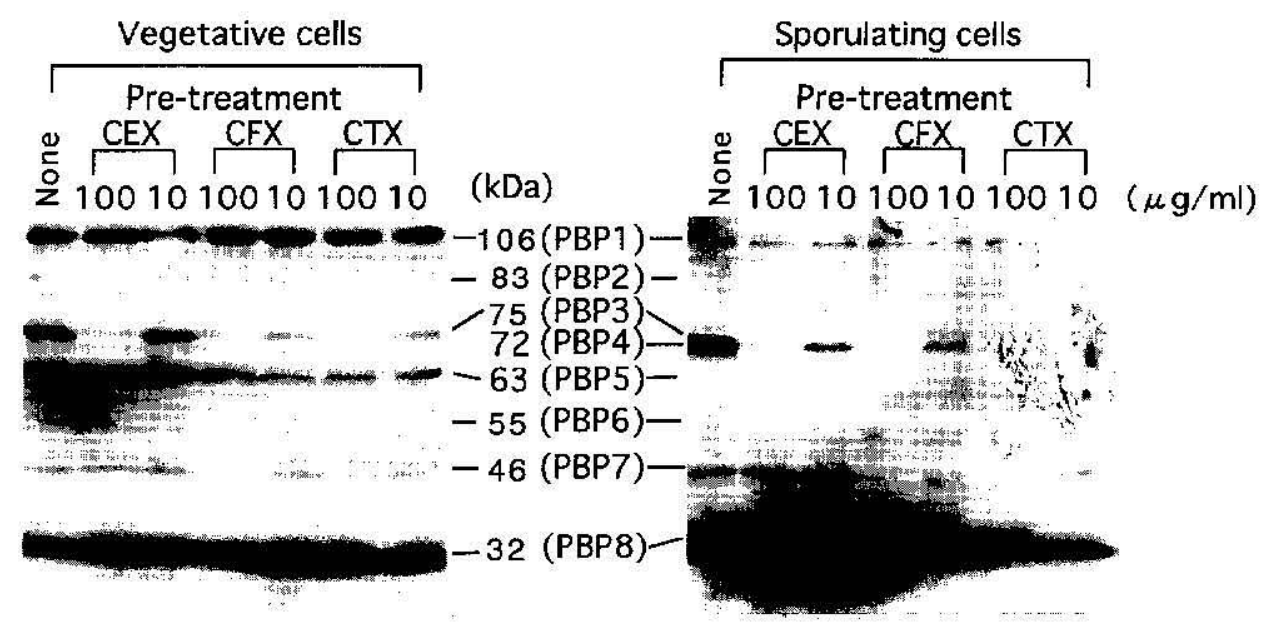

Fig. 4. SDS-PAGE profiles of PBPS of $B$. cereus ts-4 detected by biotinylated ampicillin. Membrane proteins prepared from vegetative and sporulating colls were incubated with Bio-PCA. To measure the bindings of cephalexin (CEX) and celoxitin (CFX), and cefotaxime (CTX) to PBPs, the membrane proteins were incubated with these $\beta$-lattams at, 10 and $100 \mu \mathrm{g} / \mathrm{ml}$ before addition of biotinylated ampicillin (Bio-PCA). 
membrane fraction of $B$. cereus. Comparing with standard marker proteins, these 8 PBPs were estimated for their molecular weight as $106,83,75,72,63,46,40$, and $32 \mathrm{kDa}$. The $\mathrm{PBP}$ pattern was completely same as that detected by ["H]benzylpericillin (Miyamoto et al., 1997). The sensitivity of Bio-CEX, CFX, and CTX to PBP 3, 4, and 7 in the vegetative and sporulating cells was lower than that of Bio-PCA.

SDS-PAGE profiles of PBPs prebound with cephalexin, cefoxitin and cefotaxime and labeled with Bio-PCA are shown in Fig. 4. PBI's 2, 3, 4, and 7 were decreased or disappeared in the electrophoregram by the prebinding with these $\beta$-lactams. PBPs 3 and 4 in sporulating cells were disappeared by the prebinding with all $3 \beta$-lactams at 100 and $10 \mu \mathrm{g} / \mathrm{ml}$, respectively. PBP 7 was also disappeared by the prebinding with cefoxitin and cefotaxime at $100 \mu \mathrm{g} / \mathrm{mnl}$.

\section{DISCUSSION}

A new method for identifying penicillin-binding proteins was used in this study that employed biotin-streptavidin system. Biolin-streptavidin system is widely used in the area of immunoassay, immunocytochemistry, and protein blotting (Guesdon, 1979). The fact that proteins may be directly labeled with biotin via free amino groups suggested that the free amino group of ampicillin, cephalexin, cefoxitin, and cefotaxime might also have the potential for coupling with biotin (Fig. 1).

The $E$. coli PBP pattern detected by our method using Bio-PCA perfectly resembled with the well characterized PBP pattern of it as established by the radiometric method, demonstrating the validity of this new method (Fig. 2). It should be noted here that there are several advartages in the $\mathrm{Bio}-\mathrm{P}^{\mathrm{C}} \mathrm{C} \Lambda$ method over radiometric method. First, the method is much more rapid, it takes only $20 \mathrm{~min}$ to overnight exposure after chemiluminescence reaction, compared with at least 20 day exposure for detection with $\left[{ }^{3} \mathrm{H}\right]$ penicillin. Second, the biotinylation reaction is simple, inexpensive, and free of the hazard of radioactivity. Our present labeling method is applicable to antibiotics, other antimicrobial agents, or drugs possessing frce amino groups and thus providing the ease of detection of their target sites, if the amino groups are not necessary for interaction with their target sites.

Weigel et al. (1994) used digoxigenin ester to label ampicillin for detecting PBPs. The Bio-PCA method may be superior to the method using digoxigenin labeled ampicillin in detecting bacterial PBPs, since streptavidin-conjugated multiple reporter enzymes bind to each Bio-PCA giving a high sensitivity.

Cephalosporins consist of a dihydrothiazine ring fused to a $\beta$-lactam ring (Fig. 1). Numbering of the molecule begins with the sulfur moiety, position 1. Substitutions on or in the molecule have been made at positions 1,2 , and 3 , by moving the double bond between positions 3 and 4 , and by substitution at position 7 or addition of different acyl side chains. These modifications were designed to increase the cfficacy of cephalosporins against gram-negative bacteria, which rely mainly on $\beta$-lactamases for resistance. Cephalosporins containing amino group, such as cephalexin, cefaclor, cefadroxil and cefotaxime, were highly active against sporulation of $B$. cereus ts-4, whereas ampicillin and cefoxitin, also contain a free amino group in the side chain, were not and less effective, respectively (Miyamoto et al., 1997). The sensitivity of Bio-CEX, -CFX, and 
-CTX to PBP 3,4 , and 7 in the vegetative and sporulating cells was lower than that of Bio-PCA. It has been known that the introduction of any substituents (methyl, methoxy, imino or larger side chains) at position 7 of the bicyclic nucleus of cephalosporin reduced PBP affinity of the $\beta$-lactam (Neu, 1985). It seems that the free amino group of these cephalosporins somehow has the potential in giving them binding specificity to $\operatorname{PBP}(\mathrm{s})$ essential for sporulation in $B$. cereus.

PBPs wcre detected from vegetative and sporulating cells of $B$. cereus ts -4 in the present study by the Bio-PCA method. PBP pattern of vegetative cells of wild-type JCM 2125 was also identical to that of ts -4 (data not shown). In the initial stage of sporulation, PBPs $3,4,6,7$, and 8 were detected in the membrane fraction of $B$. cereus (Fig. 3 and 4). Among them, PBP 4 was the sole PBP that increased in amount during early stages of sporulation and it has high binding activity to cephalexir, cefoxitin, and cefotaxime (Fig. 4). The PBPs of B. subtilis have been extensively characterized (Todd el al., 1983; Sowell and Buchanan, 1983; Buchanan and Sowell, 1983). Several distinct sporulation-specific PBPs have been identified (e.g. PBI $4^{*}$ and PBP $5^{*}$ ), and several more PBPs that are present in vegetative cells have been reported to increase in abundance during sporulation (e.g. PBP 2B and PBP 3). Such increases were not observed during the early stages of sporulation of $B$. cereus, except PBP 4 . This could have been the result of induction of sporulation when cells eliminate much of its vegetative proteins except those essential for survival, and synthesize new proteins essential for sporulation process and for dormancy.

We are interested in two PBPs of $B$. cereus, namely $\mathrm{PBP} 3$ and $\mathrm{PBP} 4$, though their functions are not known. Previous study with $E$. coli (Spratt, 1975) has shown that cephalexin inhibited scptum formation and it did so by inhibiting PBP 3 of that organism. Amino acid substitutions of $E$. coli PBP 3 have resulted in profound loss of its affinity to cephalexin (Hedge and Spratt, 1985). Two PBPs from $B$ subtilis were reported to be homologous to $E$. coli PBP 3. A homologous protein in B. subtilis (PBP 2B) has been shown to be required for septum formation in vegetative and sporulating division of the bacterium (Yanouri et al., 1993). The other homolog, B. subtilis SpoVD, seems to be evolutionary related to $E$. coli $\mathrm{PBP} 3$, since their respective genes, spoVD and $p b p B$, occupy similar chromosomal locations immediately upstream from a conserved gene called murE. Considered from the nature of cephalexin affinity, it seems that $B$. cereus PBP 4 and also PBP 3 probably have the functional sirnilarity with $E$. coli PBP 3 and $B$. subtilis $\mathrm{PBP} 2 \mathrm{~B}$ and/or SpoVD. We are trying to determine the genes coding PBP 3 and 4 of $B$. cereus in order to clarify the mechanism of expression and to overproduce these PBPs. These results will be reported shortly.

\section{REFERENCES}

Blumberg, P. M. and J. L. Strominger 1972 Isolation by covalent affinity chromatography of the penicillin-binding components from membranes of Bacillus subtitis. Proc. Nat. Acad. Sci. USA, 69: 3751-3755

Bradford, M. M. 1976 A rapid and sensitive method for the quantitation of microgram quantities of protein utilizing the principlc of protein-dye binding. Anal. Biochem., 72: 248-254

Buchanan, C. E. 1979 Altered membrane proteins in a mini cell-producing mutant of Bacillus subtilis. J. Bacteriol., 139: 305-307

Buchanan, C. E. and M. O. Sowell 1983 Stability and synthesis of the penicillin-binding proteins during 
sporulation. J. Bacteriol., 156: 545-551

Buchanan, C. E. and A. Gustafson 1992 Mulagenesis and mapping of the gene for a sporulation specific penicillin-binding protein in Bacillus subtilis. I. Bacteriol., 174: 5430-5435

Daniel, R. A., S. Drake, C. E. Buchanan, R. Scholle and J. Erringlon 1994 The Backllus subtilis spovD gene encodes a mother-cell-specific penicillin-binding protein required for spore morphogenesis. $J$. Mol. Biol., 235: 209-220

Galleri, M., B. Lalaye, S. Lepage, M. Jamin, J. L: Thamm, B. Joris and J. M. Frere 1993 A new highly sensitive method for the detection and quantification of penicilin-binding proteins. Biochem. $J$, 291: $19-21$

Guesdon, J., T. Ternynck and S. Avrameas, (1979). The use of avidirl-biotin interaction in immunnenzymatic techniques. J. Histochem. Cytochem., 27: 1131-1139

Hedge P. J. and B. G. Spratt. 1985 Amino acid substitulions that reduce the affinity of penicillin-binding protein 3 of Escherichia coli for cephalexin. Eur. J. Biochem. 151: 111-121

Joris, B., G. Dive, A. Henriques, P. J. Piggol, and J. M. Ghuysen 1990 The life-cycle proteins RodA of Escherichia coli and SpoXD of Bacllus subtilis have very simmilar primary structures. Mol. Microbiol., 4: 513-517

Kleppc, G. and J. L. Strominger 1979 Studies of the high molecular weight penicillin-binding proteins of Bucillus subtilis. J. Biol. Chem. 254: $4856-4862$

Laemmil, U. K. 1970 Cleavage of structural proteins during the assembly of the head of bacteriophage T4. Nature, 227: $680-685$

Miyamoto, T., K. Yamaguchi, Md. A. Sayed, R. Sasahara, K. Honjoh and S. Hatario 1997 Penicillin-binding protein sersitive to cephalexin in sporulation of Bacillus cereus, Microbiol. Res. 152: $227-232$

Neu, H. C. 1985 Relation of structural properties of beta-lactam antibiotics to antibacterial activity. $A m$. J. Med., $79: 2-1: 3$

Sowell, M. O. and C. . B uchanarl, 1983 Charnges in penicillin-binding proteins during sporulation of Bacillus subtilis. J. Bacteriol. 153: 1331-1337

Spratt, B. G. 1975 Distinct penicillin-binding proteins involved in the divisjon, elongation, and shape of Escherichia coli K-12. Proc. Nat, Acad, Sci. USA 72, 2999-3003

Suzuki , H. Y. Nishtimura, and Y. Hirota 1978 On the process of cellular division in Escherichia coli: a series of mutants of $E$. coli altered in the penicillin-binding proteins. Proc. Nat. Acad. Sci. USA 75: $664-668$

Todd, J. A., E. J. Bone, P. J. Piggot, and D. J. Ellar 1983 Differential expression of penicillin-binding protein structural genes during Bacillus subtilis sponulation. FEMS Microbiol. Lett. 18: 197-202

Waxman, D. I. and J. L. Strominger 1981 Primary structure of the $\mathrm{COOH}$-terminal membranous segment of a penicillin-sensitive enzyme purified from two Bacilli, J. Bivl. Chem., 256: 2067-2077

Weigel, L. M., J. T. Belisle, J. T., Rarlolf, J. D. and M. V. Norgard 1994 Digoxigenin-ampicillin conjugatc for detection of penicillin-binding proteins by chemiluminescence. Axtimicrob. Agents Chemother, 38: $330-336$

Wu, J. J., R. Schuch, and P. J. Piggot 1992 Characterization of a Bacillus subtilis sporulation operon that includes genes for an RNA polymerase $\sigma$ factor and for a putative DD-carboxypeptidase. $J$. Bacteriol., 174: 4885-4892

Yanouri, A., R. A. Daniel, J. Frrington and C. E. Buchanan 1993 Cloring ard sequencing of the cell division gene $p b p B$, which encodes penicillin-binding protein $2 \mathrm{~B}$ in Bacillus subtilis. J. Bacteriol. 175: $7604-7616$ 